\title{
Effect of Sclerin and 2,4-Dinitrophenol on Formation of Aminoacyl-tRNA by Mouse Liver Enzyme
}

\author{
By Susumu Or, Takaaki Kusumi, Isao MAtsui \\ and Yukio SATOMURA* \\ Faculty of Science, Osaka City University, Osaka, Japan \\ Received Scptember 25, 1971
}

\begin{abstract}
Sclerin (SCL) enhanced the formation of aminoacyl-tRN $\Lambda$ by mouse liver enzyme both in a heterologous reaction with yeast $t R N A$ and in a homologous reaction with mouse liver "pH 5 fraction" to which was added CTP. The effect of SCL has been found to involve the following two points of action; one is the stimulation of the formation of aminoacylANP accompanied with the activation of inorganic pyrophosphatase activity in " $\mathrm{pH} 5$ fraction," and the other is an increase in the incorporation of AMP and CMP into the tRXA fraction. On the other hand, 2, t-dinitrophenol (DNP) rather inhibited the pyrophosphatase activity, though its effect on aminoacyl-tRNA formation varied depending on the kind of amino acids and the reaction condition. It is assumed that SCL stimulates amino acid incorporation into the protein and cold TCA soluble fractions of liver tissue through the above-mentioned mechanism of action.
\end{abstract}

Sclerin (SCL), a physiologically active metabolite produced by a strain of Sclerotinia libertiana, stimulates the growth and enzyme formation of various seedlings such as those of castor bean, mung bean, radish, bareley and rice, ${ }^{1 \sim 31}$ and especially the growth of sugar beet. " SCL also stimutates the formation of enzymes by microorganisms such as lipase by the Sclerotinia fungus itself, ${ }^{\prime \prime}$ and amylase and protease by washed suspensions of a strain of Bacillus subtilis." SCL may influence widely the regulation of metabolisms in cells of many living organisms, where a common mechanism of action at the enzyme level may operate through plants and animals. In an experiment on animal tissue, 2,4-dinitrophenol (DNP)

* To whom requests for reprints should be addressed. Abreviations. RNA, Ribonucleic acid; tRNA, Transfer RNA; TCA, Trichloroacetic acid; ATP, Adenosine 5'-triphosphate; AMP, Adenosine 5'-phos-" phate; CTP, Cytidine 5 -triphosphate; CMP, Cytidine 5'-phosphate; $\mathrm{P}_{1}$, Orthophosphate; $\mathrm{PP}_{\mathrm{i}}$, Pyrophosphate; pC, Cytidine 5'-phosphate; Cp, Cytidine 3'-phosphate; $A$ Adenosine; $K m$, Michaelis constant. competitively repressed the effect of SGL on enzyme induction. ${ }^{31}$ In this paper, the effect of SCL and DNP on the formation of aminoacyl-tRNA by mouse liver enzyme is presented, and some aspects of the mechanism of SCL action are elucidated.

\section{MATERIALS AND METHODS}

Chemicals. Nucleotide triphosphates and yeasttRNA were purchased from Boehringer Mannheim Japan Co., Ltd. Dehydrostreptomycin sulfate was purchased from Takeda Chemical Industries Ltd. L${ }^{14} \mathrm{C}-$ Valine $(225 \mathrm{mCi} / \mathrm{mM}), \mathrm{L}^{-14} \mathrm{C}$-isoleucine $(270 \mathrm{mCi} / \mathrm{mM})$, $\mathrm{L}^{14} \mathrm{C}$-phenylalanine $(405 \mathrm{mCi} / \mathrm{mM}), \quad \mathrm{L}^{-14} \mathrm{C}-$ methionine $(5.81 \mathrm{mCi} / \mathrm{mm})$ and $8-14 \mathrm{C}-\mathrm{ATP}(49.8 \mathrm{mCi} / \mathrm{mM})$ were purchased from Daiichi Pure Chemicals Co., Ltd.

Incorporation of amino acid into liver tissue. Mice (DDT strain), which had been fed with a diet of Clea Co., Ltd. (CE-2) and water and weighed 20 to $30 \mathrm{~g}$ each, were killed by decapitation. Livers were removed and put in a chilled dish. It was sliced with a razor blade, and divided into each $100 \mathrm{mg}$ portions. Incubation was carried out in $2 \mathrm{ml}$ of Krebs-Ringer 
solution containing $2 \mathrm{mg}$ of glucose, $2 \mathrm{mg}$ of casamino acids and $6.2 \times 10^{-5} \mathrm{mCi}$ of ${ }^{14} \mathrm{C}$ - $\mathrm{U}$-labeled amino acids for $60 \mathrm{~min}$ at $37^{\circ} \mathrm{C}$ with shaking. After the incubation the slices were washed and homogenized, and the homogenate was fractionated by a modified method of Schmidt-Thanhauser-Schneider, ${ }^{5,6}$ Radioactivity was counted by an Aloka FCim $1 \mathrm{E}$ gas flow counter with a TDC-2 autoscaler.

Aminoacylation of tRNA in homologous and heterologous reactions. In the homologous reaction, the mouse liver "pH $j$ enzyme" fraction was used. The "pH 5 fraction" was prepared from the $105,000 \times g$ supernatant fraction of the liver homogenate, and $0.2 \mathrm{ml}$ of the $\mathrm{pH} 5$ fraction was preincubaled with 3 , mmoles of ATP, $4.5 \mu$ moles of $\mathrm{MgCl}_{2}$ and 30 , moles of Tris buffer $\left(\mathrm{pH} 7.7\right.$ ) for $30 \mathrm{~min}$ at $37^{\circ} \mathrm{C}$ in the presence or absence of 0.4 umole of CTP. The preincubated solution was again incubated with $0.2 \mathrm{ml}$ of the " $\mathrm{pH} 5$ fraction," 3 , moles of ATP, $4.5 \mu$ moles of $\mathrm{MgCl}_{2}$, $30 \mu$ moles of Tris buffer and $0.2 \mu$ moles of ${ }^{14} \mathrm{C}-\mathrm{U}$. labeled amino acid for $30 \mathrm{~min}$ at $37^{\circ} \mathrm{C}$ : the total volume of the incubated mixture was $1.1 \mathrm{ml}$. In the heterologous reaction, the mouse liver "streptomycin supernatant fraction" prepared according to the method of Daniel and Littauer ${ }^{7}$ was used, and $2 \mathrm{mg}$ of yeast IRNA was preincubated with $3 \mu$ moles of ATP, 4.5 $\mu$ moles of $\mathrm{MgCl}_{2}, 30$ momoles of Tris buffer (pH 7.7) and $0.1 \mathrm{ml}$ of the "streptomycin supernatant fraction" for $30 \mathrm{~min}$ at $37^{\circ} \mathrm{C}$. To the preincubated solution were added 0.2 umole of $14 \mathrm{C}-\mathrm{C}$-labeled amino acid $\left(6 \times 10^{4} \mathrm{cpm}\right), 3.0$, $:$ moles of ATP, 4.5 umoles of $\mathrm{MgCl}_{2}$, 30 moles of Tris buffer $(\mathrm{pH} 7.7)$ and $0.1 \mathrm{ml}$ of the "streptomycin supernatant fraction," and the mixture $(1.0 \mathrm{ml})$ was again incubated for $30 \mathrm{~min}$ at $37^{\circ} \mathrm{C}$. After the incubation, 27 umoles of EDT $t$ and $1.0 \mathrm{ml}$ of $70 \%$ phenol were added. The labeled aminoacylIRIA was separated by the phenol-water procedure and precipitated by the ethanol-salt precipitation. The precipitate was dissolved into $1.0 \mathrm{ml}$ of $0.1 \%$ sodium chloride solution, and $0.2 \mathrm{ml}$ of the solution were placed on a stainless steel planchette, evaporated to dryness and counted by an Aloka FC-1E 2 gas flow counter.

Incorporation of $A M P$ into $t R N A$. The extent of AMP incorporation was measured as follows: A reaction mixture $(0.45 \mathrm{ml})$ containing 20 moles of glycine buffer $\left(\mathrm{pH}\right.$ 9.4), 0.3 umole of $8{ }^{14} \mathrm{C}$-labeled ATP $\left(2 \times 10^{4} \mathrm{cpm}\right), 0.3$ umole of unlabeled CTP, 2.0 , umoles of $\mathrm{MgCl}_{2}, 5.0$ umoles of phosphoenolpyruvate, $0.02 \mathrm{ml}$ of pyruvate kinase (2.0 $/ \mathrm{g}$ of protein), $0.15 \mathrm{mg}$ of yeast tRNA and $0.1 \mathrm{~m}$ l of the "streptomycin supernatant fraction" was incubated at $37^{\circ} \mathrm{C}$ for an appropriate time. The reaction was stopped by immersing the tubes in an ice bath, and $0.5 \mathrm{ml}$ of $5 \%$ perchloric acid was added. The resulting precipitate was filtered through a millipore filter $(0.45 \%)$, and washed three times with $5 \mathrm{ml}$ portions of 10 perchloric acid. Then, the filter was transferred to a planchette, dried and counted by the gas flow counter.

MAK column chromatography. Methylated albumin was prepared as described by Mandell and Hershey. ${ }^{81}$ Column chromatography was performed according to the method of Sueoka and Yamane, ${ }^{91}$ and ${ }^{14} \mathrm{C}$ labeled aminoacyl-tRNA (1.2 mg) in $50 \mathrm{ml}$ was loaded on a $2.0 \times 17.2 \mathrm{~cm}$ column equilibrated with $0.4 \mathrm{M}$ $\mathrm{NaCl}$ and $0.2 \mathrm{M}$ phosphate buffer $(\mathrm{pH} 6.7)$. Fractions $(5 \mathrm{ml})$ were collected at a flow rate of $40 \mathrm{ml} / \mathrm{hr}$.

Formation of hydroxamic acid from aminoacyl-AMP. The method of Lipmann and Tattle10r was followed. A mixture ( $1 \mathrm{ml}$ ) containing $0.3 \mathrm{mg}$ of the "streptomycin supernatant fraction," 1.2 mmoles of salt free hydroxylamine, 10 mmoles of disodium ATP, 10 , of phenylalanine and 60 , moles of Tris buffer ( $\mathrm{pH} 7.8$ ) was incubated at $37^{\circ} \mathrm{C}$ for an appropriate time. At the end of the incubation, it was cooled to $0^{\circ} \mathrm{C}$ and mixed with $1 \mathrm{ml}$ of a ferric chloride solution ( 5 per cent in $0.1 \mathrm{~N}$ hydrochloric acid). The resulting precipitate was removed by centrifugation. The absorption of the supernatant fluid at $540 \mathrm{~nm}$ was measured against a blank containing all the components except amino acid.

Measurement of pyrophosphatase activity. A reaction mixture containing 0.33 mole of pyrophosphate, 1.7 mmoles of $\mathrm{MgCl}_{2}, 0.3 \mathrm{ml}$ of the "pH 5 fraction" and 0.33 mole of Tris buffer ( $\mathrm{pH} 7.7$ ) in the total volume of $3.3 \mathrm{ml}$ was incubated for $30 \mathrm{~min}$ at $37^{\circ} \mathrm{C}$, and $3 \mathrm{ml}$ of $5 \%$ TCA was added. Amount of $P_{i}$ released was determined by the method of Fiske-Subbarow.11

\section{RESULTS}

1. Effect of SCL and DNP on amino acid incorporation into liver tissue

As shown in Table I, SCL $\left(2 \times 10^{-5} \mathrm{M}\right)$ stimulated both the incorporation of L-valine and L-phenylalanine into the protein fraction and 
Table 1. EFFECT OF SCL and DNP on ${ }^{14} \mathrm{C}$-Amino Acids Incorporation into Liver Tissue

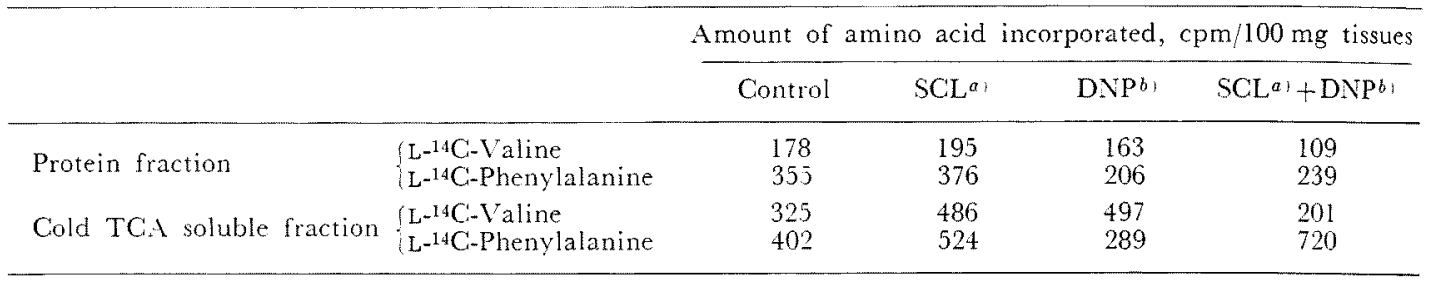

a) SCL at $2 \times 10^{-5} \mathrm{M}$.

b) DNP at $1.72 \times 10^{-5} \mathrm{M}$.

cold TCA soluble fraction of liver tissue, respectively. DNP $\left(1.72 \div 10^{-5} \mathrm{M}\right)$ inhibited the incorporation of these amino acids into the protein fraction. Although it inhibited the incorporation of phenylalanine into the cold TCA soluble fraction, it rather stimulated that of valine. The combination of SCL and DNP also inhibited the incorporation of the amino acids into the protein fraction. Although it inhibited the incorporation of valine into the cold TCA soluble fraction, it rather markedly stimulated that of phenylalanine.

2. Effect of SCL and DNP on formation of aminoacyl-tRNA in heterologous reaction with yeast $t R N A$

As shown in Table II, SCL more or less enhanced the formation of all the aminoacyltRNAs tested such as those of valyl-, phenylalanyl-, isoleucyl-, and methionyl-tRNA. DNP slightly stimulated the formation of valyl-. and phenylalanyl-tRNAs while it completely inhibited that of isoleucyl and methionyltRNAs. The effect of combination of SGL and DNP on the formation of aminoacyltRNAs varied depending on the kind of amino acids.

The effect of concentration of SCL on the formation of phenylalanyl-tRNA was presented in Fig. 1. The effect of SCL increased with the concentration and was maximum at $4 \times 10^{-5} \mathrm{M}$. The activity of the mouse liver enzyme on the formation of phenylalanyltRNA was fairly high as compared with that of the rat liver enzyme, ${ }^{12}$ in the heterologous
TABLE II. EFFECT OF SCL AND DNP ON AMINOACYLATION OF tRN A IN HETEROLOgOUS REACTION

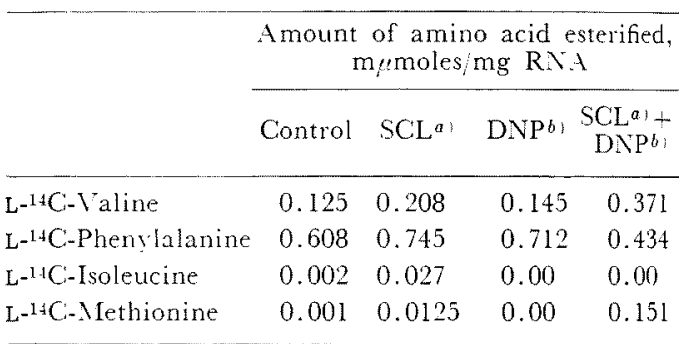

a) SCL at $2 \times 10^{-5} \mathrm{M}$.

b. DNP at $1.72 \times 10^{-5} \mathrm{M}$.

Amount of phenylalanine esterified (m $\mu$ moles/mg RNA)

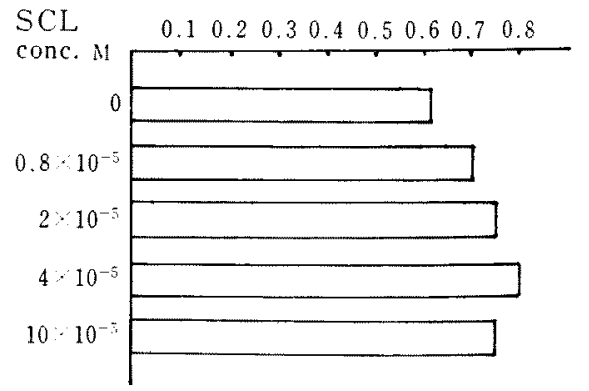

FIG. 1. Effect of Concentration of SCL on Formation of Phenylalanyl-tRNA.

reaction with yeast tRNA. As presented in Fig. 2, MAK column chromatography of ${ }^{14} \mathrm{C}$ valine-tRNAs formed in the presence or absence of SCL was carried out. While two peaks were observed in the absence of SCL, only one peak was observed in the presence 


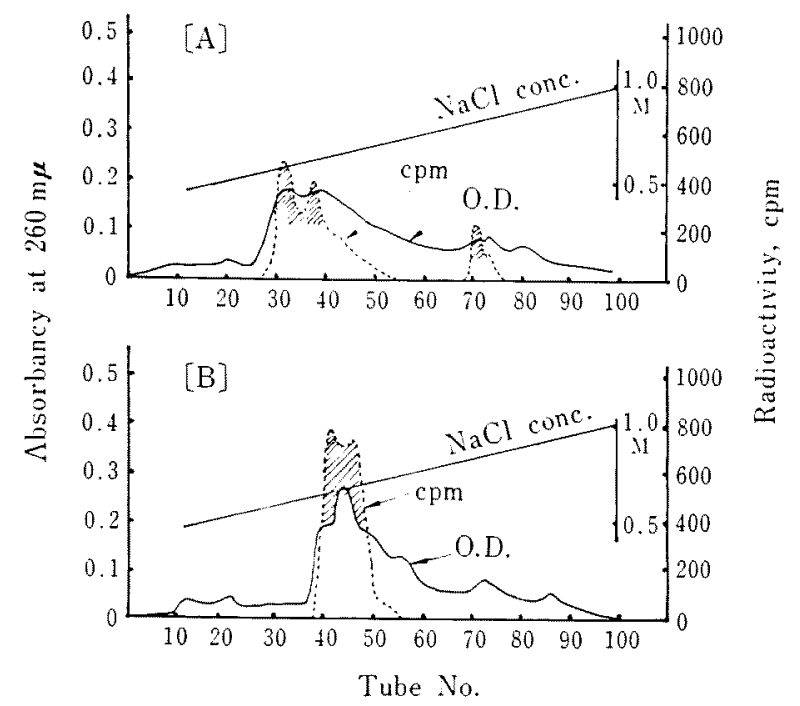

FIG. 2. MAK Column Chromatography of ${ }^{14 C-V a l i n e-t R N A . ~}$

$$
\begin{aligned}
& A,{ }^{14} \mathrm{C} \text {-valine-tRNA formed in the absence of } \mathrm{SCL} \text {. } \\
& \mathrm{B},{ }^{14} \mathrm{C} \text {-valine-tRNA formed in the presence of } \mathrm{SCL} \\
& \left(2 \times 10^{-5} \mathrm{M}\right) \text {. } \\
& \text { The procedure is described in the text. }
\end{aligned}
$$

of SCL. The main peak of the former was usually eluted at tube No. 25 to 45 and the peak of the latter was eluted at tube No. 38 to 50 with high radioactivity. These results suggest that SCL may cause a change in the molecular structure of tRNA during the incubation with the mouse liver enzyme.

\section{Effect of $S C L$ on formation of aminoacyl-AMP}

Aminoacyl-AMP was trapped with hydroxylamine, and the amino-hydroxamic acid formed was determined by colorimetry as described above. The time course for the formation of phenylalanine-hydroxamic acid in the presence or absence of SCL was presented in Fig. 3. SCL at a concentration of $1 \times 10^{-4} \mathrm{M}$ distinctly stimulated the formation of phenylalaninehydroxamic acid from the begining for $60 \mathrm{~min}$.

\section{Effect of SCL and DNP on pyrophosphatase} activity in " $p H 5$ fraction"

As shown in Table III, pyrophosphatase

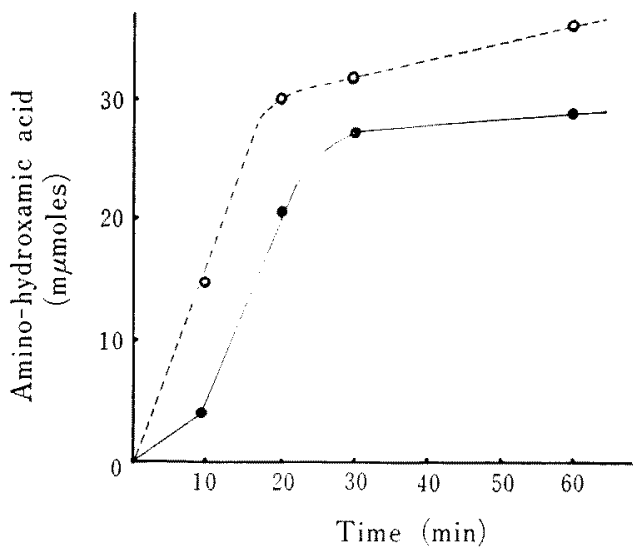

Fig. 3. Time Course of Amino-Hydroxamic Acid Formation.

O--. SCL added at $1 \times 10^{-4} \mathrm{M}$;

Phenylalanine was used.

activity in the "pH 5 fraction" was stimulated by SCL $\left(2 \times 10^{-5} \mathrm{M}\right)$, but it was inhibited by DNP $\left(1.72 \times 10^{-5} \mathrm{M}\right)$ and also by a combination of SCL and DNP The effect of the concen- 
TABle III. EFFeCt of SCL AND DNP ON PYroPhOSPHATASE ACtIVITy IN "pH 5 Fraction"

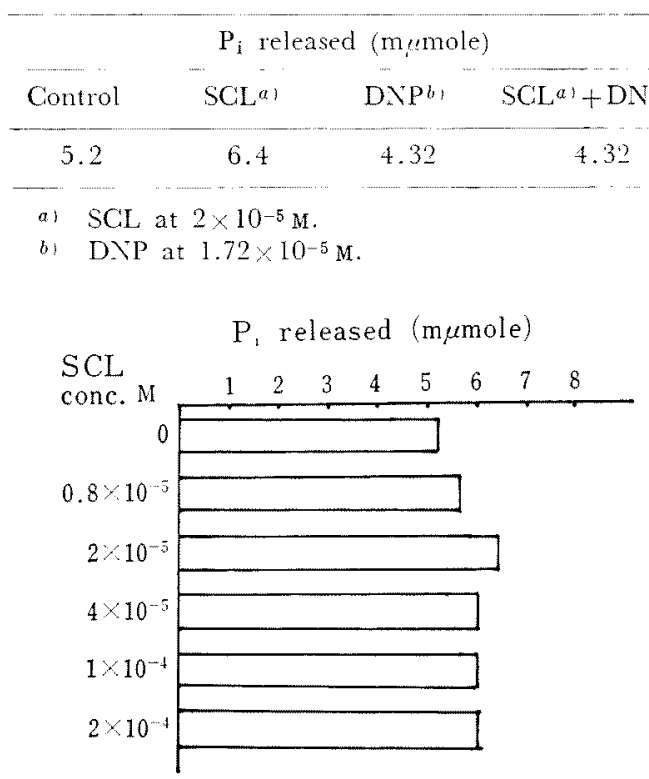

FIG. 4. Effect of Concentration of SCL on Prrophosphatase Activity in "pH 5 Fraction."

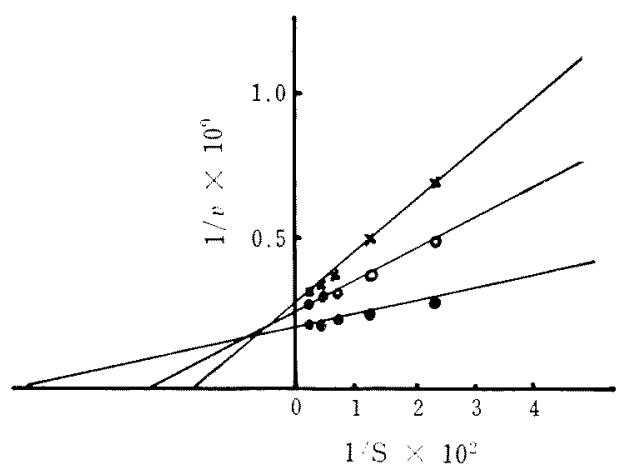

FIG. 5. Lineweaver-Burk Plot for Effect of SCL and DNP on Pyrophosphatase Activity in "pH 5 Fraction."

O-O Control; DNP $\left(1.72 \times 10^{-5} \mathrm{M}\right)$.

tration of SCL on pyrophosphatase activity in the " $\mathrm{pH} 5$ fraction" was presented in Fig. 4. The effect of SCL was maximum at a concentration of $210^{-5} \mathrm{M}$. The Lineweaver-
Burk plot for the effect of SCL and DNP on pyrophosphatase activity was presented in Fig. 5. SCL had an effect of lowering the $K m$ value, and DNP showed a mixed type of inhibition.

\section{Effect of $S C L$ on aminoacylation of $t R N A$ in} the presence of pyrophosphate

As shown in Table IV, while the formation of aminoacyl-tRNAs in the presence of pyrophosphate at a concentration of $10^{-6} \mathrm{M}$ was completely inhibited, it was restored by SCL at a concentration of $2 \times 10^{-5} \mathrm{M}$ both in the heterologous and homologous reactions.

TABLE IV. EFFECT OF SCL ON AMINOACYLATION of tRNA in the Presence of Pyrophosphate

Formation of ${ }^{14} \mathrm{C}$-valine-tRNA in the presence of $P P_{i}$ at $10^{-6} M$ was determined as described in the text.

\begin{tabular}{lcc}
\hline & $\begin{array}{c}\text { Amount of amino } \\
\text { acid esterified, } \\
\text { (mimoles/mg RNA) }\end{array}$ \\
\cline { 2 - 3 } & Control & $\begin{array}{c}\text { SCL } \\
\left(2 \times 10^{-5} \mathrm{M}\right)\end{array}$ \\
Heterologous reaction & 0.00 & 1.34 \\
Homologous reaction & 0.00 & 0.16 \\
\hline
\end{tabular}

6. Effect of $S C L$ and DNP on aminoacylation of $t R N A$ with homologous reaction in the presence or absence of CTP

As shown in Table $\mathrm{V}$, in the homologous reaction DNP $\left(1.72 \times 10^{-5} \mathrm{M}\right)$ rather stimulated the aminoacylation of tRNA in the absence of CTP, while SCL $\left(2 \times 10^{-5} \mathrm{M}\right)$ did not. On the other hand, SCL markedly stimulated the aminoacylation of $t R N A$ in the presence of CTP, while DNP inhibited conversely. The effect of a combination of SCL and DNP was. also inhibitory.

7. Effect of SCL and CTP on AMP incorporation into tRNA

As shown in Table VI, the effect of SCL and CTP on the incorporation of AMP from 
TABLE V. EFFECT OF SCL AND DNP ON AMINOACYLATION OF tRNA WITH HOMOLOGOUS REACTION IN THE PRESENCE OF CTP

Formation of ${ }^{14} \mathrm{C}-\mathrm{valine}-\mathrm{RNA}$ with the homologous reaction in the presence or absence of CTP was determined as described in the text.

\begin{tabular}{|c|c|c|c|c|}
\hline & \multicolumn{4}{|c|}{$\begin{array}{l}\text { Amount of amino acid esterified, } \\
\qquad(\mathrm{m} \mu \text { moles/mg RNA) }\end{array}$} \\
\hline & Control & $\mathrm{SCL}^{a}$ & $\mathrm{DNP}^{b}$ & $\mathrm{SCL} a^{a}+\mathrm{DN}^{\top} \mathrm{P}^{b}$ \\
\hline None & 0.24 & 0.20 & 0.51 & 0.23 \\
\hline $\mathrm{CTP}^{\mathrm{s}}$ & 0.40 & 1.61 & 0.05 & 0.10 \\
\hline
\end{tabular}

a) SCL at $2 \times 10^{-5} \mathrm{M}$.

b) DNP at $1.72 \times 10^{-5} \mathrm{M}$.

c) CTP, in 0.4 umole.

TABLE VI. EFFECT OF SCL AND CTP ON AMP INCORPORATION INTO TRNA

\begin{tabular}{|c|c|c|c|c|}
\hline & $\begin{array}{r}\text { Amoun } \\
20 \mathrm{~m}\end{array}$ & $\begin{array}{l}\text { of } A M \\
\text { in, } m_{\ell} \ell n\end{array}$ & $\begin{array}{l}\text { incorpor } \\
\text { oles/mg R }\end{array}$ & $\begin{array}{l}\text { ated in } \\
\text { NA }\end{array}$ \\
\hline & $\begin{array}{l}\text { in the } \\
\text { of } \mathrm{C}\end{array}$ & $\begin{array}{l}\text { absence } \\
\text { TPal }\end{array}$ & $\begin{array}{l}\text { in the } \mathrm{p} \\
\text { of } \mathrm{C}\end{array}$ & $\begin{array}{l}\text { resence } \\
\mathrm{TP}^{a}\end{array}$ \\
\hline & Control & $\mathrm{SCL}^{b}$ & Control & $\mathrm{SCL}^{b}$ \\
\hline $\begin{array}{l}\text { Preincubated } \\
\text { yeast tRNAc }\end{array}$ & 3.10 & t. 20 & 3.70 & 5.20 \\
\hline $\begin{array}{l}\text { Untreated } \\
\text { yeast tRNA }\end{array}$ & 6.10 & 6.80 & 6.20 & 8.16 \\
\hline $\begin{array}{l}\text { a) CTP at } 3 \times \\
\text { b) SCL at } 2 \times \\
\text { ") Yeast tRN } \\
\text { of the "streptom } \\
\text { of Tris buffer ( } \mathrm{P} \\
\text { by the phenol } \mathrm{m} \\
\text { in the text. }\end{array}$ & $\begin{array}{l}10^{-7} \mathrm{M} \text {. } \\
10^{-5} \mathrm{M} \text {. } \\
5 \mathrm{mg} \\
\text { cin supe } \\
(7.7) \text { for } \\
\text { thod. T }\end{array}$ & $\begin{array}{l}\text { ras preit } \\
\text { natant } \\
2 \text { hr at } \\
\text { he condi }\end{array}$ & $\begin{array}{l}\text { cubated } \\
\text { action" } \\
7{ }^{\circ} \mathrm{C} \text {, and } \\
\text { ions are }\end{array}$ & $\begin{array}{l}\text { ith } 1 \mathrm{ml} \\
\text { nd } 1 \mathrm{ml} \\
\text { eparated } \\
\text { lescribed }\end{array}$ \\
\hline
\end{tabular}

ATP into yeast tRNA was examined. SCL $\left(2 \times 10^{-5} \mathrm{M}\right)$ only increased remarkably the rate of AMP incorporation in the presence of CTP $\left(3 \times 10^{-7} \mathrm{M}\right)$ in $20 \mathrm{~min}$. However, when yeast tRNA was preincubated with the "streptomycin supernatant fraction," SCL remarkably increased the rate of AMP incorporation both in the presence and absence of CTP. Also, as presented in Fig. 6, AMP incorporation into preincubated tRNA in the absence of CTP was stimulated by SCL at the begining, but the stimulation did not extend further

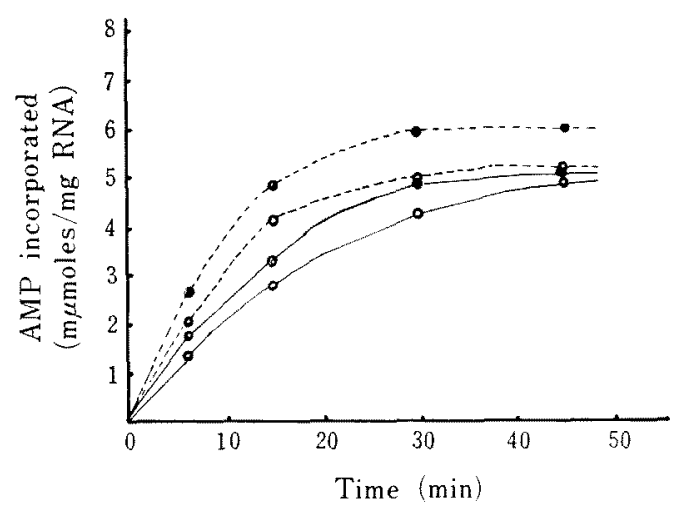

FIG. 6. Time Course of Incorporation of A AL into Preincubated Yeast tRNA.

Control
SCL at $2 \times 10^{-5} \mathrm{M} /\left(3 \times 10^{-7} \mathrm{M}\right)$
C-O Control
SCL at $2 \times 10^{-5} \mathrm{M}$, in absence of CTP
reast tRNA was preincubated with the "strepto-
mycin supernatant fraction" as in Table VI.

and attained to an equilibrium within $60 \mathrm{~min}$. On the other hand, in the presence of CTP, the extent of AMP incorporation was finally increased by SCL. These results indicate that SCL stimulates the incorporation into RNA of nucleotides such as AMP and CMP which construct the -pCipCpA end of tRNA.

\section{DISCLISSION}

Cantoni ${ }^{13)}$ has already found that yeast pyrophosphatase enhances the formation of serinetRNA ( $E$. coli) by a highly purified enzyme from yeast in a manner analogous to macromolecular "enhancing factor" in yeast. According to Jacobson, ${ }^{241}$ the fractionation procedure of the "enhancing factor" is, indeed, appropriate for pyrophosphatase, too. Inorganic pyrophosphate would be a potent inhibitor of the formation of aminoacyl-tRNAs in the heterologous reaction. It is interesting that SCL stimulates the formation of aminoacyltRNAs with a simultaneous increase in the activity of pyrophosphatase in the mouse liver "pH 5 fraction." The effect of SCL may 
partly be due to a prevention of inhibition by pyrophosphate. SCL lowers the $K m$ value of pyrophosphatase, although DNP shows a mixed type of inhibition, and DNP does not have a unifying effect on the formation of aminoacyl-tRNAs under the experimental conditions. SCL stimulates the reaction velocity in the time course of the formation of aminoacyl-AMP, from the begining, where the effect of pyrophosphate may be negligible. Accordingly, it is conceivable that SGL and DNP have a close connection with the specificity of aminoacyl-tRNA synthetase per se, respectively.

It is known that, in the heterologous reaction, mischarging of tRNA occurs under various conditions. ${ }^{15}$ As shown in the above experiment, in the absence of SCL, two chromatographically distinct ${ }^{14} \mathrm{C}$-valine-tRNAs have been formed from a yeast tRNA preparation, while, in the presence of SCL, only one identical ${ }^{14} \mathrm{C}$-valine-tRNA separated by a column chromatography. SCL may prevent the mischarging of tRNA by arranging the molecular structure of tRNA. tRNA chains, particularly in yeast tRNA preparations, predominantly terminates in cytidine, ${ }^{16)}$ and preincubation of yeast tRNA with the "streptomycin supernatant fraction" might remove the terminal cytidine. SCL stimulates the incorporation of AMP and CMP into tRNA, as described above. Therefore, SCL must enhance the extent of the formation of aminoacyl-tRNAs by constructing promptly the -pCpCpA end of tRNA.

SCL facillitates amino acid incorporation into the protein fraction of liver tissue, while DNP inhibits, as described above. There may be involved a still unknown effect in the protein synthesis. However, it seems reasonable to assume that the main effect of SCL on the protein synthesis is involved in the formation of aminoacyl-tRNAs.

\section{REFERENCES}

1) I'. Satomura and A. Sato, Agr. Biol. Chem., 29, 337 (1965).

2) T. Kubota, T. Tokoroyama, T. Kamikawa and Y. Satomura, Tetrahedron Letters, No. 42, 5205 (1966).

3) Y. Satomura, Chemical Regulation of Plants, Vol. 3, No. 2, 127 (1968).

4) Datum from the Murphy Chemical Co. Ltd. in England (1968).

5) W. C. Schneider, J. Biol. Chem, 164, 747 (1956).

6) S. Mizuno, "Seikagaku-Jikkenho A-2" (Japanese), Tokyo Univ. Press, 1969, p. 19.

7) V. Daniel and U. Z. Littauer, J. Mol. Biol., 11, 693 (1965).

8) J. D. Mandell and A. D. Hershey, Anal. Biochem., 1, 66 (1960).

9) N. Sueoka and T. Yamane, Proc. Natl. Acad. Sci. U.S., 51, 642 (1964).

10) F. Lipmann and L. C. Tattle, J. Biol. Chem., 159, 21 (1945).

11) C. H. Fiske and Y. Subbarow, ibid., 66, 375 (1925).

12) B. P. Doctor and J. A. Mudd, ibid., 238, 3677 (1963).

13) G. L. Cantoni, personal communication to K. B. Jacobson, Advances in Nucleic Acid Research and Molecular Biology, 11, 472 (1971).

14) F. K. Kull, P. O. Ritter and K. B. Jacobson, Biochemistry, 8, 3015 (1969).

15) K. B. Jacobson, Advances in Nucleic Acid Research and Molecular Biology, 11, 469 (1971).

16) K. Tanaka, "Procedures in Nucleic Acid Research," Harper and Row Press, New York, 1967 p. 475 . 